\title{
Is irrigation water price an effective leverage for water management? An empirical study in the middle reaches of the Heihe River basin
}

\author{
Qing Zhou ${ }^{\mathrm{a}, \mathrm{b}, \mathrm{c}}$, Feng $\mathrm{Wu}^{\mathrm{b}, \mathrm{c}}$, Qian Zhang ${ }^{\mathrm{b}, \mathrm{c}, *}$ \\ a University of Chinese Academy of Sciences, Beijing 10049, China \\ ${ }^{\mathrm{b}}$ Institute of Geographic Sciences and Natural Resources Research, Chinese Academy of Sciences, Beijing 100101, China \\ ${ }^{\mathrm{c}}$ Center for Chinese Agricultural Policy, Chinese Academy of Sciences, Beijing 100101, China
}

\section{A R T I C L E I N F O}

\section{Article history:}

Received 31 January 2015

Received in revised form 5 September 2015

Accepted 21 September 2015

Available online 16 October 2015

\section{Keywords:}

Water scarcity

Agricultural irrigation water demand

Water price

Price elasticity

Farmers' response

Heihe River basin

\begin{abstract}
A B S T R A C T
Serious water scarcity, low water-use efficiency, and over-exploitation of underground water have hindered socio-economic development and led to environmental degradation in the Heihe River basin, northwestern China. Price leveraging is an important tool in water demand management, and it is considered to be effective in promoting water conservation and improving water use efficiency on the premise that water demand is elastic. In the present study, we examine whether price is an effective and applicable instrument for restraining the increasing demand for agricultural irrigation water in the middle reaches of the Heihe River basin and how will it affect farmers' decisions on irrigation and crop structure. Specifically, the price elasticity of agricultural water demand was estimated based on the irrigation water demand function. The results show that the agricultural irrigation water price is statistically significant, but its elasticity is very low under current low water price. Price leverage cannot play a significant role in the context of the current pricing regime and farmers' response to price increase is intrinsically weak. To create incentives for conserving water and improving irrigation efficiency, price mechanism should be accompanied with clearly defined and legally enforceable water rights, restricted water quota measures, and reform of water authorities and water-user associations. Furthermore, increases of surface irrigation water price may lead to the over-withdrawal of groundwater, consequently, effective groundwater licensing and levying must take place to limit the total volume of groundwater withdrawal. In all, improving irrigation efficiency through better management and the adoption of water-saving technologies is the ultimate way to deal with the challenges facing irrigated agriculture in the middle reaches of the Heihe River basin.
\end{abstract}

(c) 2015 Elsevier Ltd. All rights reserved.

\section{Introduction}

Water is not only essential for organisms to live on this planet, but also highly significant to local, national, and global economic development. Water risk has been identified as one of the top ten crises in global development (Charles et al., 2000). China faces a very serious water crisis, as it has $20 \%$ of the world's population but only 5-7\% of global freshwater resources (Piao et al., 2010). How to utilize water resources in a sustainable way has become a focus for Chinese society. A falling supply of water has contributed to water scarcity in the country, which has been aggravated by the rising water demand from different sectors. Essentially, the scarcity represents the conflict between China's

* Corresponding author at: Institute of Geographic Sciences and Natura Resources Research, Chinese Academy of Sciences, Beijing 100101, China.

E-mail address: zhangq.ccap@igsnrr.ac.cn (Q. Zhang). thirsty farms and cities (Deng et al., 2015; Li et al., 2015). Agriculture, as the main water-using sector in China, consumes about $60 \%$ of the total water resource. However, the rapidly developing industrial sector and an increasingly wealthy urban population have started to compete with agriculture for water (Cheng, 2002; Deng et al., 2008, 2014; Jiang et al., 2014). Because the diminishing surface water resources can no longer satisfy the demand for water for the purpose of irrigation, farmers have begun to rely more on groundwater resource. The increasing amount of groundwater used for agricultural purposes has made the over-extraction of underground water a very serious problem in northwestern China. The over-exploitation of groundwater, especially deep groundwater, can cause a number of environmental problems, such as land desertification and a reduction in the amount of natural vegetation cover (Qiu, 2010; Deng and Zhao, 2014). Furthermore, water use inefficiency and water waste are still prevalent and are the main reasons for the current water crisis in northwestern China (Shi 
et al., 2015). The irrigation water quotas and water consumption per unit of GDP are very high and the average irrigation quota per acre of farmland is $522 \mathrm{~m}^{3}$, which is almost $25 \%$ higher than the national average, and the water consumption per 10,000 yuan GDP is $1736 \mathrm{~m}^{3}$, or $85 \%$ higher than the national average (Wang et al., 2007).

Undoubtedly, as rapid development of industrialization and urbanization, water demand will increase in the future, and the conflict between water supply and demand will be more fiercer in arid and semi-arid regions such as northwestern China (Cheng et al., 2014; Li et al., 2014). There is an imperative need to investigate the management of water demand and the market mechanism for water allocation so that the current mode of extensive agricultural water use can be transformed. Price control and quota control are the two main water demand management strategies (Wang et al., 2015). The extensive quota management usually fails to reduce the water demand for the poor administrative management and less-stringent quota regulations (Wang et al., 2013a,b). On the other hand, price control which is based on market mechanism has been given a high priority hoping that the reasonable price signals can regulate the extravagant water consumption and promote water conservation and the rational allocation of water resources (Huang et al., 2010; Shen and Lein, 2010). Water pricing, as an important socio-economic tool, is considered the most effective way to advance water allocation and water conservation by several scholars (Tiwari and Dinar, 2001; Robert et al., 2002). According to Dinar and Subramanian (1998), water pricing could reveal the economic and scarcity value of this valuable resource and encourages water users to utilize water resources more wisely (Dinar and Subramanian, 1998). Furthermore, prices could guide farmers to adopt irrigation technologies with high irrigation efficiency or to change to a more productive cropping pattern (Adusumilli et al., 2011; Schoengold et al., 2006).

Underpricing of irrigation water is frequently identified as the primary cause of excessive use of water for irrigation. Many researchers and policy makers reckons that water in agriculture is consistently undervalued since users do not value it and thus lead to a chronically overuse of it (Seagraves and Easter, 1983; Wang, 2007). Although agricultural water demand is high in northwestern China, the irrigation water price is relatively low, accounting for only one-third of its production cost. The price elasticity of the derived demand for irrigation water is an economic measure that is often used to evaluate the effectiveness of price incentives in facilitating water conservation. There were studies on water price elasticity and its influence on water utility, and the previous research findings in several countries have revealed that the demand for irrigation water is inelastic because the price is too low (Ogg and Gollehon, 1989; Schoengold and Zilberman, 2007). Further, simulation analysis has shown that when the price of water is raised to a relatively high level, the pricing can promote water savings (Huang et al., 2010). On the other hand, some studies still doubt about the water saving effects and the economic consequences and other external effects like agricultural production reduction, rural poverty and over-utilization of groundwater resources brought by increasing water price (Liao et al., 2007; Venot and Molle, 2008).

To date, most existing studies of agricultural water use and irrigation water prices in northwestern China have been qualitative, and quantitative relationship between water demand and price are under-examined (Guo et al., 2006; Ma et al., 2009). This paper analyzes the effectiveness of the use of pricing mechanism as a policy tool in dealing with water stress in irrigated agriculture under the current water management system in northwestern China, which leads to two key research questions: Is price really an effective instrument in controlling water demand under current circumstance? Can increasing water price really promote water conservation and how will it influence farmers' decisions and crop production? To answer the two research questions, we analyze price responsiveness in irrigation water demand based on the water demand function to figure out the relationship and influencing mechanisms between irrigation water price and water demand. We then analyze the impact of increasing water price on farmers' income, crop structure and groundwater extraction. Consequently, and the policy recommendations aiming to adaptive water management were developed on the basis of the research findings. The selected study area is the Middle Reaches of Heihe River basin because of its severe water stress and substantial role of grain production in China.

\section{Study area}

The Heihe River, the longest inland river in Gansu province and the second largest inland river in China, originates from the Qilianshan Mountains and ends in Lake Juyanhai in Inner Mongolia. The Heihe River flows through three major geomorphological units: the southern Qilian Mountains in its upper reaches, the Hexi Corridor in its middle reaches, and the northern Alxa High Plain in its lower reaches. The study area Zhangye, one of the prefectural cities of Gansu province, is located in the middle reaches of the Heihe River basin. Zhangye city covers an area of $42,000 \mathrm{~km}^{2}$ and has six counties under its governance, which are Ganzhou, Shandan, Minle, Gaotai, Linze, and Sunan. Except for Sunan, the other five counties are typical irrigated agriculture area, which are the selected study areas of this study. The total population of Zhangye city is $1,278,000$ people, of whom about 834,000 live in rural areas. The mean annual precipitation in Zhangye city ranges from less than $100 \mathrm{~mm}$ to $250 \mathrm{~mm}$, and is therefore a typical arid to semi-arid region. Zhangye city is the main agricultural area in the Heihe River basin. The farmland in Zhangye city covers an area of 238,000 ha and accounts for $95 \%$ of the total farmland in the basin, and about $90 \%$ of the farmland area is irrigated (Gansu Statistical Yearbook, 2009). The majority of water in the middle reaches is used for agriculture irrigation, meaning that there is little water left to maintain the ecological services in the lower reaches of the river in Ejina Banner $(\mathrm{Q} i)$, which has led to serious deterioration of the downstream ecological environment. To alleviate the conflict between agricultural water use in the middle reaches of the Heihe River and the ecological water demand in the lower reaches, a water allocation program was officially launched in 2000 . Through water diversion, the downstream ecological environment has improved in recent years (Lu et al., 2015). However, the internal water competition is now much fiercer in the middle reaches since there is less water supply but with more agricultural, industrial and domestic water demand.

Agricultural water use accounts for about $95 \%$ of the total water use in Zhangye, and irrigation accounts for $85 \%$ of the total agricultural water use (MWR bulletin, 2009). The total amount of water for irrigation is still increasing year on year, but the speed of the increase is slowing down because of the quota measures taken by the local government. With the low annual precipitation and the increasing agricultural water demand, farmers have had to draw more groundwater. The total amounts of water used for irrigation and the groundwater component have both grown in recent years (Fig. 1). Both the total amount of water used for agricultural purposes and the acreage of agriculture are increasing, and as a result the water demand is unable to be satisfied.

Agricultural water-use efficiency is very low in Zhangye currently, namely between $20 \%$ and $30 \%$, far lower than that in the developed countries. Inefficient irrigation methods, such as flood and furrow irrigation, are still the main irrigation modes, and water-saving irrigation modes like pipeline and drip irrigation 


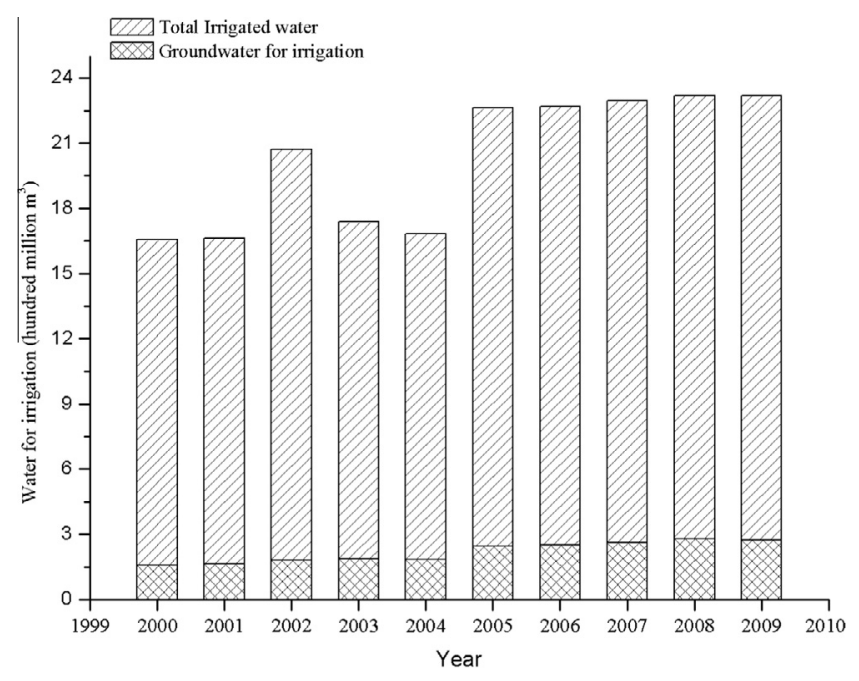

Fig. 1. Total and the groundwater for irrigation in Zhangye from 2000 to 2009.

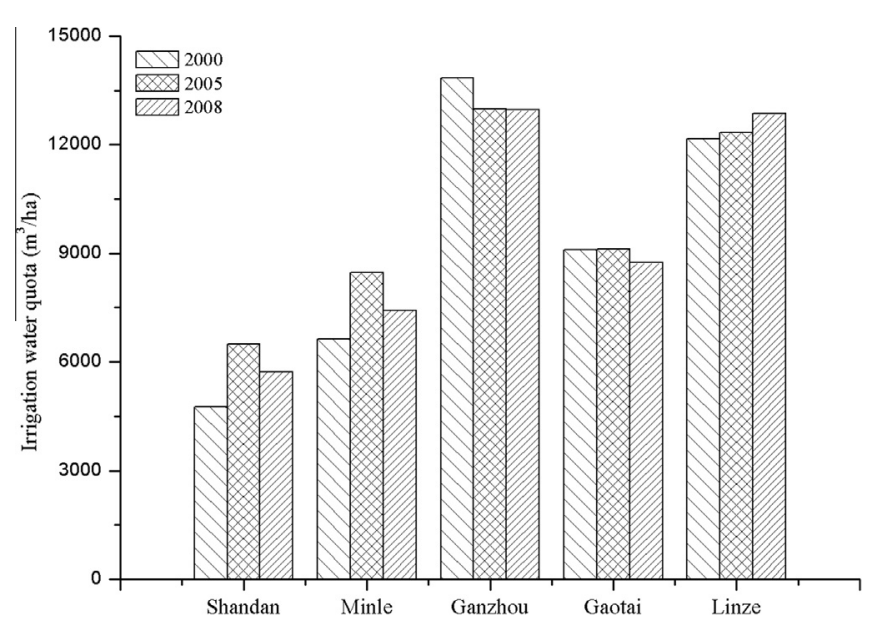

Fig. 2. Irrigation water quota per hectare in five counties of Zhangye.

are not widely used in this region. The irrigation water quota per hectare varies in different counties across years (Fig. 2). On average, irrigation water quota per hectare of Ganzhou and Linze doubled Shandan and Minle. Gaotai used a volume $30-40 \%$ less than Ganzhou and Linze. The different water quotas also reflect the different water stress level in the five counties. The irrigation water amount shows a trend to decrease first and then increase in Ganzhou and Gaotai. Part of the reason of the decrease in 2005 maybe the water conserving program launched in 2002, which Zhangye was authorized the first pilot of water conserving society in China. Since then, water saving technologies have been adopted and crop structure has been optimized. Whereas, the decreasing trend doesn't persistent for a long time, a turning point occurred in year 2008 approximately.

Although Zhangye faces a situation of serious water scarcity, water-use efficiency is still very low in this region due to inefficient agricultural irrigation. One reason for the low efficiency is the low water price for agriculture, since low water price leads to the failure of price mechanism to effectively regulate water markets and water allocation. Researchers and officials have argued that unreasonable water demand should be constrained by raising water price. Meanwhile, it is imperative to recognize the product attributes of water resources and to reflect the scarcity of water through the market mechanism, in order to promote water conservation and protection through price leveraging (Wang et al., 2005, 2007; Guo, 2006; Liao et al., 2007).

\section{Methods and data}

\subsection{Basic theory}

Price elasticity is a measure of the responsiveness of the quantity of a raw good or service demanded to its price change (MasColell et al., 1995). It can be represented as the percentage change in quantity demanded in response to a one percent price change when keeping other determinants of demand constant. The coefficient of price elasticity can be written as:

$e_{(p)}=\frac{d Q / Q}{d P / P}$

where $P$ is price, $Q$ is demand, and $e_{(p)}$ is price elasticity (usually a negative value).

Based on economic theory, we use the water demand curves to represent two kinds of elasticity: high water demand elasticity (elastic demand) and low water demand elasticity (inelastic demand) (Yang et al., 2003). Elasticity of water demand changes at different levels of water rates. With the same increase of the price, from $\mathrm{p} 1$ to $\mathrm{p} 2$, when the demand is elastic (Fig. 3a), there is a big decrease in the water demand from Q2 to Q1, comparatively the reduction of the demand is relative small when the water demand elasticity is low. Under the inelastic situation, farmers make a very small or zero response to price increases, and therefore, there is no distinct change in existing crop structure and water demand, but only farmer's income declines. On the contrary, above the price threshold, farmers respond actively to price increases by reducing water use. Under this situation, farmers either substitute their traditional crops with those that consume less water, or/and shift to higher value-added crops so that each unit of water use can generate more value.

\subsection{Irrigation water demand function}

There are three main types of demand function model: the linear demand function model, the semi-logarithmic demand function model, and the log-linear demand function model. Because the model parameters of the log-linear demand function have an explicit economic interpretation (expressed as price elasticity), it is widely used for economic forecasting. The elasticity is the same at any point on the demand curve (Wang et al., 2013a,b). The form of the log-linear function is expressed as:

$x=A P^{\beta_{1}} M^{\beta_{2}} e^{\sigma}$

From Eq. (2), by taking the natural logarithm on both sides, the formula can be rewritten as:

$\ln x=a+\beta_{1} \ln P+\beta_{2} \ln M+\sigma$

$\beta_{1}=\frac{\Delta \ln x}{\Delta \ln P} \quad \beta_{2}=\frac{\Delta \ln x}{\Delta \ln M}$

where $P$ is price, $M$ is other influencing factors, $\beta_{1}$ is the price elasticities of demand.

In this paper, we concentrated on the price elasticity of surface irrigation water demand. Numbers of wells and ratio of groundwater used in irrigation were used to eliminate the influence of groundwater use on surface water demand. In addition to the effect of water price, irrigation water demand is also affected by farmers' income, precipitation, evaporation, crop structure (i.e., the sawn areas and water requirements of different crops), and water conservation technologies adopted (Pei et al., 2003). In 

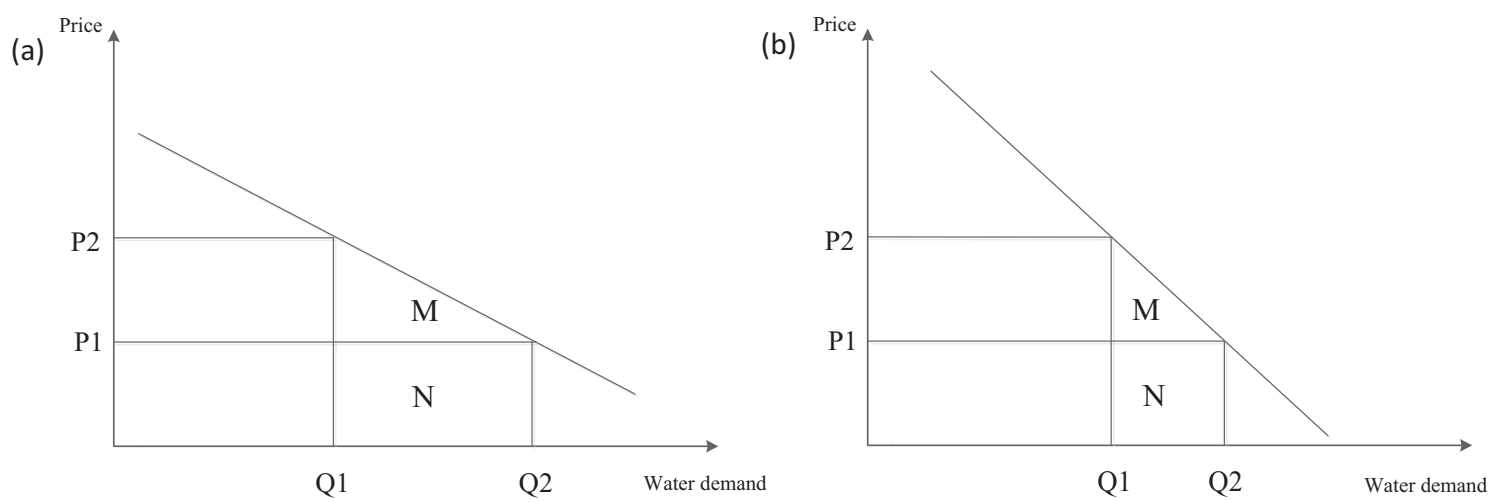

Fig. 3. Elastic and inelastic water demand curves: (a) high water demand elasticity; (b) low water demand elasticity.

particular, precipitation and crop structure cannot be neglected in the agricultural water demand function. In this study, the crop structure is represented by the ratio of economic crops and grain crops. The main grain crops in Zhangye city are the rain-fed crops, such as maize and wheat, and they have similar water requirements. Economic crops include vegetables, cottons and oil seeds. The annual rainfall varies in different counties, ranges from 100 to $400 \mathrm{~mm}$ which may have some impact on irrigation water demand, but not very significant. Water conservation technologies have been applied in the study area in recent years, and there is consequently no distinct change in water-saving technology during our study period from 2000 to 2009. There is also little change for evaporation in the short term. Although we have identified the main factors that may affect irrigation water demand, some of the factors may be considered constant or essentially invariant for our study, such as irrigation mode and evaporation. Therefore, we merged these factors into a random variable. Accordingly, the specific model of the relationship between irrigation water demand and water price can be expressed as:

$q=A p^{\beta_{1}} r^{\beta_{2}} i^{\beta_{3}} g^{\beta_{4}} W^{\beta_{5}} s^{\beta_{6}}$

In the logarithm form:

$\ln q=a+\beta_{1} \ln p+\beta_{2} \ln r+\beta_{3} \ln i+\beta_{4} \ln g+\beta_{5} \ln w+\beta_{6} \ln s+\varepsilon$

where $q$ is the irrigation water demand, $p$ is the water price, $r$ is the rainfall in the corresponding year, $i$ is famers' income, $g$ is groundwater ratio, $w$ is number of wells and $s$ represents crop structure. $\beta_{1}$ is the water price elasticity of demand, $\beta_{2}$ is effect of rainfall, $\beta_{3}$ is the income elasticity, $\beta_{4}$ and $\beta_{5}$ are the influence of groundwater exploitation on surface water demand, $\beta_{6}$ is effect of crop structure and $\varepsilon$ is an error term.

\subsection{Data source}

In order to obtain water price elasticity of irrigation water demand, data on irrigation water demand and precipitation for the 2000-2009 study periods are taken from the Water Resources Bulletin for each year (MWR, 2000-2009). Irrigation water demand was usually represented by irrigation water quota or/and the actual water usage per hectare. In our model, the actual water usage per hectare was adopted to represent the irrigation water demand in order to reflect the real water consumption status. The data on farmers' income, sawn area of main crops (maize, wheat and other crops) of the five counties are collected from Yearbooks of Zhangye (Zhangye Yearbook, 2000-2012). The agricultural irrigation water price was collected from survey data and previous literature (Guo et al., 2006). Taking into account the long sequence of value pricing for 10 years, the prices may have been affected by the inflation of the domestic commodity price, we therefore modified the prices using the rural area retail price index, taking 2009 as the base year.

\section{Results and discussion}

\subsection{Results analysis}

To obtain the water demand function model, we estimated the natural logarithm of variables using ordinary least squares (OLS) regression. The adjusted $R^{2}$ value for the model is 0.89 , indicating that the independent variables in the model explain $89 \%$ of the variation of the dependent variable.

From the results of the regression, the water demand function model is expressed as:

$$
\begin{aligned}
\ln q & =3.7-\underset{(0.062)}{0.55} \ln \text { price }-0.4 \underset{(0.113)}{\ln } \underset{\text { ground_ratio }}{0}+0.03 \underset{(0.07)}{\ln } \text { plant_ratio } \\
R^{2} & =0.89, F=10.8
\end{aligned}
$$

The elasticity of the irrigation water price is -0.55 and is significant at the $5 \%$ confidence level with a $t$ value of 4.6 . The elasticity value indicates that water demand for irrigation will decrease by $0.55 \%$ when the water price increased by $1 \%$. With reference to the study of Pei et al. (2003), this elasticity value lies within the empirical reliable interval of between -0.5 and -3.0 . From an economic perspective, irrigation water price can be regarded as being inelastic in that the price is at the stage that farmers have no incentive to reduce the irrigation water demand or change their irrigation mode. The low elasticity casts light on the conflicts between the low irrigation water price and the huge water demand of Zhangye.

The coefficient of groundwater ratio is also significantly negative, which confirms that irrigated groundwater can offset the amount of surface water for irrigation. In Zhangye, groundwater used for irrigation accounts for almost $30 \%$ of the total irrigation and the proportion is still increasing annually facing the diminishing surface water (Shi et al., 2011). The ratio between economic crop sawn area and grain crop sawn area also has some impacts on irrigation water demand. The regression result shows that the more the sawn area of economic crop, the more water was demanded. That's because the economic crop are more water intensive vegetables and oil seeds. The coefficients of precipitation and income are very small and not significant in our estimated model. Part of the reason may be that Zhangye lies in semi-arid region and the precipitation is little and its influence on water demand correspondingly. 
In Zhangye, agricultural water price is very low. The average surface water price for agriculture was only 0.071 yuan per cubic meter before 2011 , and it has now increased to 0.1 yuan per cubic meter. However, surface water still cannot cover its cost even at a price of 0.15 yuan per cubic meter (Xian et al., 2014). The price of groundwater, which is just 0.05 yuan per cubic meter, is very low. Because of the low prices, farmers have no incentive to change their inefficient irrigation modes and to adopt new irrigation skills or to purchase more expensive but efficient equipments. Since price elasticity of irrigation water demand changes at different levels of water prices, the price increase will lead to the increase of the elasticity, and thus a more responsive feedback occur between farmers and the irrigation water markets (Qin et al., 2010). We are able to conclude that the agricultural irrigation water price may be a potential policy instrument to manage the high irrigation water demand in Zhangye, but irrigation surface water price is still at a relatively low level and currently is not very elastic. However, the elasticity of water demand will increase as water price increases, and there is certainly scope for the water price to increase.

\subsection{Impacts of Irrigation water price reform on water saving, cropping pattern and groundwater extraction}

\subsubsection{Influence on water saving}

The current irrigation water price is very low in Zhangye, which can hardly cover its cost. Furthermore, the irrigation cost is only a small portion of crop farming, namely less than $10 \%$ of the total input of crop production. The local government has issued a standard for levying agriculture irrigation water tariff. The water tariff consists of two parts, the basic tariff and the metering tariff. Charges for canal, pipeline and drip irrigation uses a unified price (Guo et al., 2006). For groundwater, the cost of irrigation is primarily the expense of power and pumping equipments. Water resource itself is almost free. No restriction is imposed on the volume of water extraction in each well, though digging new wells in principle requires the approval of water authorities. Farmers measure their irrigation cost by electricity and fuel bills and the concept of water cost is generally absent. In this context, the number of wells is thus continually increasing in recent years.

Based on the average amount of irrigation water per hectare, the water demand shows a slightly decrease trend when facing an increasing water price. It indicates that increasing water price helps to promote water saving and induce a transform of the traditional irrigation mode. In Zhangye city, water price is still very low, about $60 \%$ of its cost. The price of surface irrigation water and its supply cost of each county are shown in Fig. 4. Shandan has the highest water price which is nearly 0.1 yuan per cubic meter, and it is about $70 \%$ of its cost. In other counties, the proportion is also higher than $60 \%$. Comparing to the inputs and outputs of agricultural production, there is still space for price to increase.

Generally, different water rates may cause very disparate water utilization behaviors considering the cost for implementing the water conserving technology. When the price is far below the cost for new technology adoption, the traditional irrigation mode will not be abandoned and water saving will merely come from reduction of irrigation water. But when price is increased to its cost that is higher than the cost for new technology adoption, new irrigation technology will be promoted and the extravagant irrigation mode will be given up.

Considering the low water price elasticity of irrigation water demand in Zhangye, implementing the price instrument may not be very effective currently. Another problem should be considered is that when the price is higher than groundwater extraction cost, farmers will have the motivation to dig more wells and use more groundwater for irrigation. The current well management is not

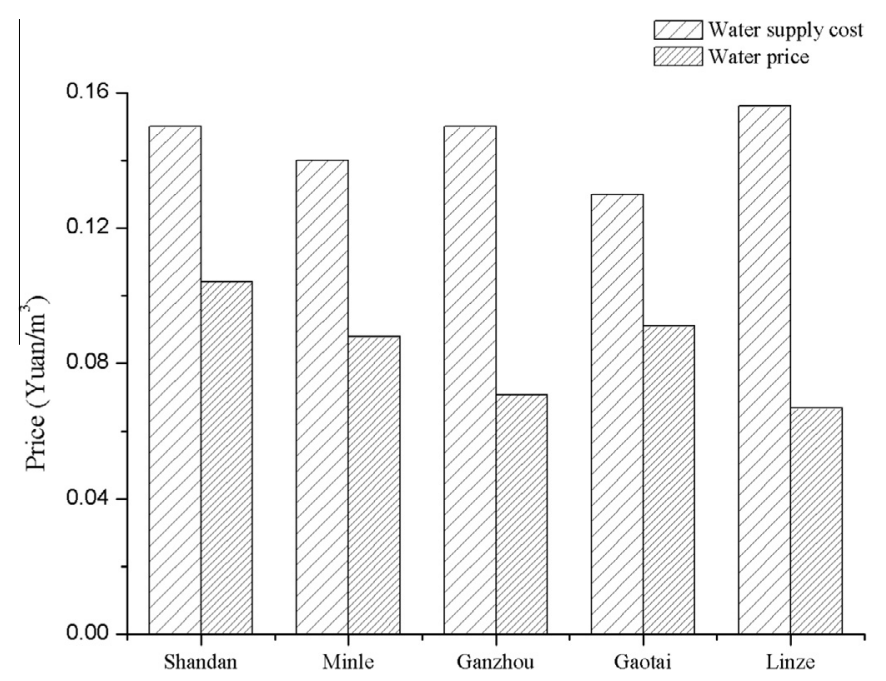

Fig. 4. Water supply cost and water price of irrigation areas for each county in Zhangye (year 2008).

strict and over-extraction of groundwater is very common in not only Zhangye, but also many China's cities. Though the sole increases of water price may not very effective at current stage, price leverage can still be a potential instrument when combined with other measures, such as quota measure, to alleviate the increasing water demand.

\subsubsection{Influence on cropping pattern}

Since the 1950s, Zhangye city has been a commercial grainproducing base established by the Central Government of China (Zhang, 2007). It has a double cropping system with wheat growing in winter and maize in summer. Before year 2000, more than $70 \%$ of sawn area in Zhangye was wheat and maize. In recent years, changes in agricultural policy in China have allowed farmers to choose their crops and more cash crops (such as alfalfa and vegetables) were planted in order to increase farmers' income. In 2008, the sawn area of vegetables increased by nearly $20 \%$. But grain farming was still dominant in Zhangye city and the water intensive maize and wheat are still the main crops (Fig. 5). Among these crops, maize is the most water intensive one. The average water requirements in the growing period for wheat and maize are $602 \mathrm{~mm}$ and $500 \mathrm{~mm}$ respectively. Although water resource is limited, farmers still plant a lot of maize, which requires more water for its growth compared to the other crops.

With the intensification of water scarcity, shifting to higher added value crops has been promoted strongly in recent years. This increasing trend is really obvious in Ganzhou and Gaotai, where the economic crop accounts for more than 30\% and 50\% respectively. The rationale is that the shift could generate higher output value with a given amount of water, which means that water productivity is higher correspondingly. Increase of water price will also affect farmers' crops planting structure preference in a long run. Additionally, crop planting structure is more likely to be influenced by governmental policies and market situation. From the perspective to saving water and enhancing water productivity merely, high water consumption for low added value crops should be substituted by the production of high added value crops, only if the minimum grain production demand is satisfied.

\subsubsection{Influence on groundwater extraction}

With limited surface water resources, increasing water price and water demand, groundwater extraction is a feasible substitution in arid Zhangye. Groundwater for irrigation has been 


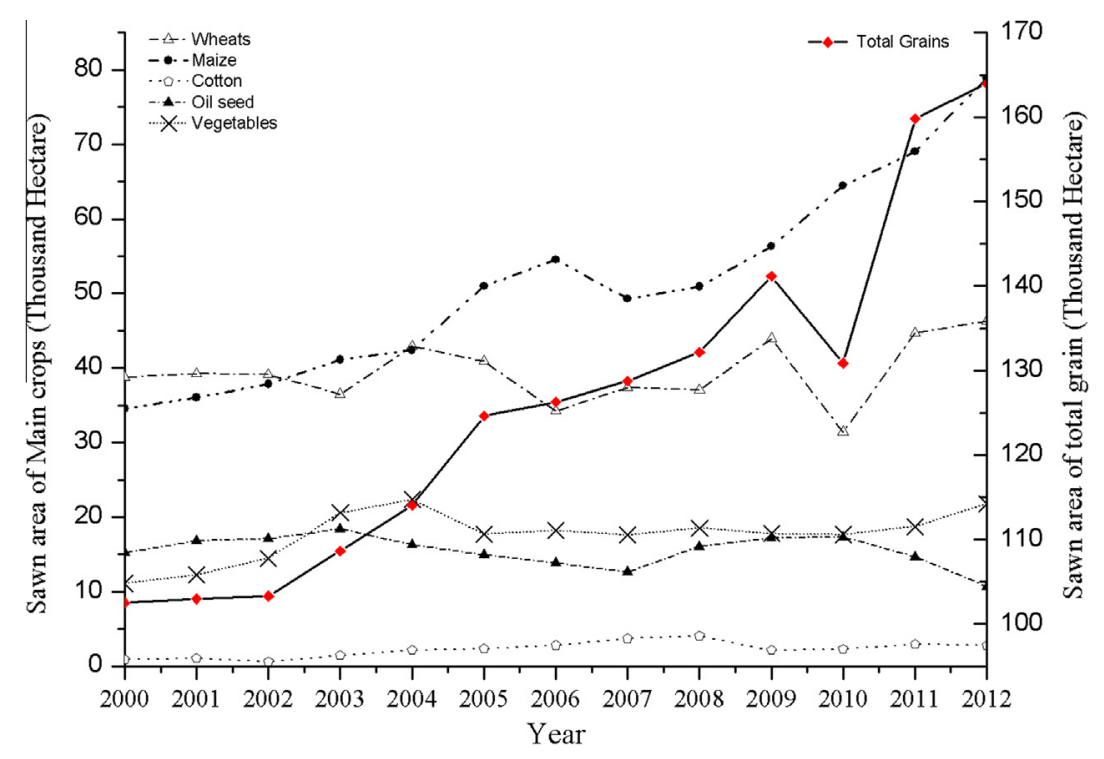

Fig. 5. Changes in planting area of the main crops grown in Zhangye from 2000 to 2012 ( $y$-axis unit: 1000 ha).

increased by more than $70 \%$ since year 2000 , and the number of wells has been increased by $25 \%$.

In Zhangye, each pump is operated independently and serves only a small group of farmers. The irrigation management is taken primarily by village collectives and, to a much lesser extent, by individual farmers who acquired well leases from collectives (Wang et al., 2000). The licensing system for new wells is not effective. Villagers dig new wells subject only to the financial constraint and resource availability. Furthermore, as water resource itself is free, the only cost is electric power and the expense for digging a well.

Increasing surface irrigation water price may lead to a further overexploitation of groundwater considering the low price of groundwater and the unrestricted extraction of groundwater on existing wells and the not effectively enforced control on digging new wells. Consequently, it is imperative and urgent to implement strict groundwater management and levy groundwater resource. Imposing a groundwater resource levy may not completely alleviate water scarcity. For this reason, introducing the groundwater resource levy must be taken in parallel with a restriction on the total volume of water-withdrawal, an improvement in watersaving irrigation technologies, and promotion of industrial transformation.

\subsection{Farmers' response to increased water price}

The low water price elasticity reflects farmers' weak response to increase of irrigation water price in Zhangye city. The perverse impacts of water price increases on agricultural output and farm income are partly because the current water price is far below the shadow price of water resource, which is estimated as the marginal product value based on the production function theory. When price is far below the shadow price, farmers have little incentive to invest in the application of water-saving irrigation technologies or to reduce their sown area. When price is in the efficient price range where the price elasticity of water demand is high, pricing leverage would be an effective instrument since it would provide the necessary incentives for farmers to adapt to the rising prices by using irrigation water more efficiently, giving up extravagant irrigation methods, such as flood and furrow irrigation, and adopting more efficient water-saving irrigation modes, such as spray irrigation and drip irrigation.
Although an increase in water price could lead to a decrease in agricultural water use, it does not necessarily mean that a water price increase would be a good measure. From experience of other countries, farmers' water use decisions are very unresponsive to changes in the price of water when the elasticity is low, large price increases would cause relatively small reductions in irrigation water use, but large negative effects on agricultural income and wealth (Berbel and Gomez-Limon, 2000; Feng, 1999). Moreover, if the water cost accounts for more than $20 \%$ of farmers' income, a price hike would hurt farmers' enthusiasm for production, particularly grain crops, will most likely to decline facing increasing irrigation water cost (Tang and $\mathrm{Xu}, 2009$ ). This could have a series of impacts on regional economy and trade. Food imports, especially the import of cereal grains, would increase. Accordingly, there is trade-off between water consumption reduction and the regional agriculture and economic development based on the price responsiveness.

Furthermore, except for the increasing production cost, the responsiveness of farmers' water use to different prices is influenced by many other factors, for instance, water management systems, market conditions, availability of substitute crops, farmers' freedom in decision making for agricultural production, and the overall status of rural and urban economic development (Yusuyunjiang et al., 2014; Li et al., 2014). All these factors should be considered when implementing the price mechanism.

From year 2015, in order to control irrigation water demand, irrigation water price reform has been launched in Gaotai and Minle as pilots. The surface water price was increased from 0.1 to 0.2 yuan per cubic meter, and groundwater tariff was increased by 10 times from 0.01 to 0.1 yuan per cubic meter (Xie, 2015). The sharp increase of the water price may have some impacts on cutting the extravagant water demand and leading farmers to choose less water intensive crops and/or higher water productivity plants, namely the plants with higher economic return per cubic meter water. The effects of the new water price reform have not been examined in this study because it is too short (only a few months) to do field investigation and collect the data for farmers' responses after water price reform. Nevertheless, it is worthwhile to investigate the dynamics (similarities and differences) of the farmers' behaviors before and after the water price reform to examine the effects of water price increase in more depth. Although the recent five years has not been considered in this 
study, we can still observe the relationship between the irrigation water demand and irrigation water price, and find that the price leveraging effects is little under low water price level.

\section{Conclusions}

Low water prices have been widely disparaged for the low efficiency in irrigation systems. Farmers have little incentive to conserve water and to adopt new water-saving irrigation technologies. In this paper, we attempted to investigate how irrigation water demand would respond to changes in water price, and whether water price is an appropriate and applicable instrument to mitigate water shortage and to improve water-use efficiency under the current situation in Zhangye. By analyzing water consumption and water price status of the study area of Zhangye and by including the main factors that may affect agricultural irrigation water demand, we constructed an agricultural irrigation water demand price elasticity model. In our empirical model, agricultural irrigation water price is statistically significant, but the price elasticity is still very low. It indicates that the current irrigation water price is still inelastic and its leveraging effects cannot mitigate the rampant demand efficiently. The analysis demonstrates that under the current irrigation management system, further increasing irrigation price may not serve the purpose of water conservation. The response of farmers' behaviors to irrigation water price signals is intrinsically weak. For farmers, increasing irrigation water prices means a loss of income, but little change in their water-usage behaviors. Additionally, the increasing water price may result in more groundwater extraction. A sharp increase of water price is not suitable for the middle reaches of the Heihe River Basin. A gradually increasing water price is recommended. Meanwhile, when setting a price for water, farmers' response should be fully considered and the water cost should not exceed farmers' tolerance. A rational water price should reflect its market value and simultaneously consider farmers' incomes and levels of tolerance.

In order to implement an integrated water conservation policy, the water pricing leverage should work together with other measures of water conservation, such as water rights, water user associations and water quota control mechanism. Clearly defined and legally enforceable water rights and responsibilities of both water authorities and farmers enables them to sell saved water to other farmers or other sectors thus leading a reallocation of water resource to users who can produce higher added values. Moreover, water rights strategy is also imperative for generating endogenous forces for innovation, diffusion and adoption of water-saving irrigation technologies. Quota control has very substantial water saving effects, but its implementation is not strict and it may bring about the reduction of crop production. Therefore, it should be integrated with water price leverage. Furthermore, groundwater extraction restriction through effective water licensing must take place to limit the total volume of groundwater withdrawal.

The findings of this study of agricultural water demand and pricing in Zhangye shed light on the efficient use of agricultural water and adaptive water resource management. The results also indicated that using the pricing mechanism as a single policy tool to deal with water scarcity may not be effective and in many ways lead to results contrary to the objectives of the policy itself. Improving irrigation efficiency through better management and the adoption of water-saving irrigation technologies is the ultimate way to tackle with the challenges facing irrigated agriculture.

\section{Conflicts of interest}

The authors declare no conflicts of interests.

\section{Acknowledgments}

This research was financially supported by a grant from the major research plan of the National Natural Science Foundation of China (Grant No. 91425303). Data support from the research projects of the National Natural Science Foundation of China (Grant No. 91325302; Grant No. 71225005) is also acknowledged.

\section{References}

Adusumilli, N.C., Rister, M.E., Lacewell, R.D., 2011. Estimation of Irrigation Water Demand: A Case Study for the Texas High Plains. Selected Paper presented at the Southern Agricultural Economics Association Annual Meeting, February, pp. $5-8$.

Berbel, J., Gomez-Limon, J., 2000. The impact of water-pricing policy in Spain: an analysis of three irrigated areas. Agric. Water Manage. 43, 219-238.

Charles, J.C., Pamela, G., Joseph, S., 2000. Global water resources: vulnerability from climate change and population growth. Science 289 (5477), 284-288.

Cheng, G., 2002. Study on the sustainable development in Heihe River watershed from the view of ecological economics. J. Glaciol. Geocryol. 24, 335-343.

Cheng, G., Li, X., Zhao, W., Xu, Z., Feng, Q., Xiao, S., Xiao, H., 2014. Integrated study of the water-ecosystem-economy in the Heihe River Basin. Natl. Sci. Rev. 1 (3), 413-428.

Deng, X., Zhao, C., 2014. Identification of water scarcity and providing solutions for adapting to climate changes in the Heihe River Basin of China. Adv. Meteorol. 5, $1-13$.

Deng, X., Huang, J., Rozelle, S., Uchida, E., 2008. Growth, population and industrialization, and urban land expansion of China. J. Urban Econ. 63 (1), 96-115.

Deng, X., Zhang, F., Wang, Z., Li, X., Zhang, T., 2014. An extended input output table compiled for analyzing water demand and consumption at county level in China. Sustainability 6, 3301-3320.

Deng, X., Shi, Q., Zhang, Q., Shi, C., Yin, F., 2015. Impacts of land use and land cover changes on surface energy and water balance in the Heihe River Basin of China, 2000-2010. Phys. Chem. Earth 79, 2-10.

Dinar, A., Subramanian, A., 1998. Policy implications from water pricing experiences in various countries. Water Policy 1, 239-250.

Feng, Y., 1999. On water price determination and fee collection in irrigation districts. Water Econ. 4, 46-49.

Gansu Statistical Yearbook, 2000-2012.

Guo, M., 2006. Establishment of water-saving agriculture and reform of irrigation water price. Agric. Res. Arid Areas 24 (2), 122-124.

Guo, Q., Feng, Q., Si, J., 2006. Discuss on water price of irrigation area in middle reaches of Heihe River. J. Desert Res. 26 (5), 855-860.

Huang, Q., Rozelle, S., Richard, H., Wang, J., Huang, J., 2010. Irrigation water demand and implications for water pricing policy in rural China. Environ. Dev. Econ. 15 (3), 293-319.

Jiang, L., Wu, F., Liu, Y., Deng, X., 2014. Modeling the impacts of urbanization and industrial transformation on water resources in China: an integrated hydroeconomic CGE analysis. Sustainability 6, 7586-7600.

Li, M., Yang, J., Tan, C., 2014. Change of agricultural planting structure and its causes in the Shuangta irrigation district in the Shulehe River Basin. J. Nat. Resour. 28 (7), 1117-1129.

Li, Z., Deng, X., Wu, F., Shaikh, S.H., 2015. Scenario analysis for water resources in response to land use change in the middle and upper reaches of the Heihe River Basin. Sustainability 7, 3086-3108.

Liao, Y., Giordano, M., de Fraiture, C., 2007. An empirical analysis of the impacts of irrigation pricing reforms in China. Water Policy 9 (S1), 45-46.

Lu, Z., Wei, Y., Xiao, H., Zou, S., Ren, J., Lyle, C., 2015. Trade-offs between midstream agricultural production and downstream ecological sustainability in the Heihe River basin in the past half century. Agric. Water Manage. 152, 233-242.

Ma, J., Xia, J., Liu, X., Liu, J., 2009. Comparison between irrigation water prices in China and Australia and the policy reform of water price in China. Resour. Sci. 31 (9), 1529-1534.

Mas-Colell, A., Winston, M.D., Green, J.R., 1995. Microeconomic Theory. Oxford University Press, New York.

Ministry of Water Resources (MWR), 2000-2009. Gansu Water Resources Bulletin.

Ogg, C.W., Gollehon, N.R., 1989. Western irrigation response to pumping costs: a water demand analysis using climatic regions. Water Resour. Res. 25 (5), $767-$ 773.

Pei, Y., Fang, L., Luo, L., 2003. Price elasticity of agricultural water demand in China. Resour. Sci. 25 (6), 25-31.

Piao, S., Ciais, P., Huang, Y., Shen, Z., Peng, S., Li, J., Zhou, L., Liu, H., Ma, Y., Ding, Y., 2010. The impacts of climate change on water resources and agriculture in China. Nature 467, 43-51.

Qin, C., Zhao, Y., Pei, Y., 2010. Study on utility of generalized water resources utilization by adjustment of agricultural water price. J. Hydraul. Eng. 41 (9), 1094-1100.

Qiu, J., 2010. China faces up to groundwater crisis. Nature 466 (7304), 308.

Robert, C., Johansson, D., Yacov, T., Terry, L.R., Rachid, D., Ariel, D., 2002. Pricing irrigation water: a review of theory and practice. Water Policy 4 (2), 173-199.

Schoengold, K., Zilberman, D., 2007. The economics of water, irrigation, and development. Handbook Agric. Econ. 3, 2933-2977. 
Schoengold, K., Sunding, D.L., Moreno, G., 2006. Price elasticity reconsidered: panel estimation of an agricultural water demand function. Water Resour. Res. 42 (9), 137-238.

Seagraves, J.A., Easter, K.W., 1983. Pricing irrigation water in developing countries. Water Resour. Bull. 19, 663-672.

Shen, Y., Lein, H., 2010. Treating water as an economic good: policies and practices in irrigation agriculture in Xinjiang, China. Geogr. J. 176, 124-137.

Shi, M., Wang, L., Wang, X., 2011. A study on changes and driving factors of agricultural water supply and demand in Zhangye after water reallocation of the Heihe River. Resour. Sci. 33 (8), 1489-1497.

Shi, Q., Chen, S., Shi, C., Wang, Z., Deng, X., 2015. The impact of industrial transformation on water use efficiency in Northwest region of China. Sustainability 7, 56-74.

Tang, Z., Xu, Z., 2009. The farmers' bearing capacity of irrigation water price assessed by CVM-taking Zhangye Municipality as a case. J. Glaciol. Geocryol. 31 (3), 560-564.

Tiwari, D., Dinar, A., 2001. Role and Use of Economic Incentives in Irrigated Agriculture. Working Paper. World Bank, Washington, DC.

Venot, J., Molle, F., 2008. Groundwater depletion in the Jordan Highlands: can pricing policies regulate irrigation water use? Water Resour. Manage. 22 (12), 1925-1941.

Wang, Y., 2007. An evaluation on the institutional reforms of water pricing, water rights and water market in China. China Popul., Resour. Environ. 17 (5), 153158.

Wang, J., Huang, J., Rozelle, S., 2000. Theoretical explanations of property rights innovation in the groundwater irrigation system-an empirical study of small scale water projects. Econ. Res. 4, 66-74.
Wang, J., Huang, J., Rozelle, S., 2005. Evolution of tubewell ownership and production in the North China Plain. Aust. J. Agric. Resour. Econ. 49, 177-195.

Wang, J., Huang, J., Rozelle, S., Huang, Q., Blanke, A., 2007. Agriculture and groundwater development in Northern China: trends, institutional responses, and policy options. Water Policy 9 (S1), 61-74.

Wang, W., Cao, H., Cai, H., 2013a. Study of the relationship between irrigation water price and irrigation water demand. J. Irrig. Drainage 32 (2), 82-86.

Wang, X., Shi, M., Wang, L., 2013b. Solutions to water scarcity in arid regions: effectiveness of water demand management policy. J. Nat. Resour. 28 (7), 1117 1129.

Wang, Z., Yang, J., Deng, X., Lan, X., 2015. Optimal water resources allocation under the constraint of land use in the Heihe River Basin of China. Sustainability 7, $1558-1575$.

Xian, W., Xu, Z., Deng, X., 2014. Agricultural irrigation water price based on full cost recovery: a case study in Ganzhou District of Zhangye Municipality. J. Glaciol Geocryol. 36 (2), 462-468.

Xie, L., 2015. Review of Agricultural Water Price Reform Pilot Work in Gaotai <http://www.zgzyw.com.cn/news/system/2015/06/01/010003506.shtml>.

Yang, H., Zhang, X., Zehnder, A.J.B., 2003. Water scarcity, pricing mechanism and institutional reform in northern China irrigated agriculture. Agric. Water Manage. 61 (2), 143-161.

Yusuyunjiang, M., Til, F., Isabel, S., Reiner, D., 2014. Irrigation in the Tarim Basin, China: farmers' response to changes in water pricing practices. Environ. Earth Sci. 73 (2), 559-569.

Zhang, J., 2007. Barriers to water markets in the Heihe River basin in northwest China. Agric. Water Manage. 87 (1), 32-40.

Zhangye Year Book, 2000-2012. 